Selcuk Journal of Agriculture and Food Sciences

http://sjafs.selcuk.edu.tr/sjafs/index

Research Article
SJAFS

(2019) 33 (2), 94-98

e-ISSN: $2458-8377$

DOI:10.15316/SJAFS.2019.162

\title{
Some Reproductive Characteristics of Hasak and Hasmer Sheep: 1. Some Fertil- ity Criteria
}

\author{
Uğur TRABZON $^{1 *}$, Ayhan ÖZTÜRK ${ }^{2}$ \\ ${ }^{1}$ Bahri Dağdaş International Agricultural Research Institute, Konya, Turkey \\ ${ }^{2}$ Selçuk University, Faculty of Agriculture, Department of Animal Science, Konya, Turkey
}

\begin{tabular}{l}
\hline ARTICLE INFO \\
\hline Article history: \\
Received date: 19.04 .2019 \\
Accepted date: 31.05 .2019 \\
\hline Edited by: \\
İbrahim AYTEKIN; Selçuk University, \\
Turkey \\
Reviewed by: \\
Mehmet KOYUNCU; Uludağ Univer- \\
sity, Turkey \\
Birol DAĞ; Selcuk University,Turkey \\
\hline Keywords: \\
Hasak \\
Hasmer \\
Reproduction \\
Sheep
\end{tabular}

\begin{abstract}
In this study, Hasak and Hasmer ewes were used in order to determine the effects of age, year and breed on the conception rate, prolificacy, viability and productivity. The least-squares means for these parameters of all flock were found as follows; $87.27 \pm 0.01 \%, \quad 117.16 \pm 0.01 \%, 87.06 \pm 0.01 \%$ and $103.34 \pm 0.02 \%$, respectively. In addition, the effects of sex of lamb and birth type on viability were also studied. Except for prolificacy, effects of the age on these parameters were found to be not statistically significant. The maximum prolificacy was obtained with 6-years old ewes. Effect of breed was significant on the prolificacy $(\mathrm{P}<0.05)$ and conception rate $(\mathrm{P}<0.01)$. With regard to prolificacy, Hasmer ewes were superior to Hasak (120.90\% vs. $113.41 \%)$. The year factor had a significant effect only on the prolificacy $(\mathrm{P}<0.05)$. Sex effect on the viability was not significant, but birth type effected viability significantly; single lambs being superior to twin ones.
\end{abstract}

\section{Introduction}

The primary objective in sheep breeding used in terms of many yields should be the quality fleece and meat production, because the sheep have lower chance to compete with cattle in terms of milk production. In the future, the primary target of the world's sheep breeding will be considered as meat production. When saying the meat production from sheep, the lamb meat must come to mind. More economical and much more lamb production is directly related to the traits of ration used in breeding activity and to the genotypic structures of both ewe and lamb.

Because the great majority of existing sheep are dual purpose and primitive looking breeds in Turkey, a significant number of researches/studies have been conducted in order to obtain new sheep types with superior yield traits over a century from the proclamation of the republic to the present. In the first study started in the mid-1930s and other studies that followed it, there were tried to develop sheep types with high yield and quality of fleece and with also good meat yields. Karacabey and Central Anatolian merino can be given as the examples of these studies. In 1986, a national project was initiated in order to develop the meat sheep breeding and six different breeds of rams and ewes were brought from UK, Germany and France. Crossbreeding was done in several government enterprises through these breeds (Tekin et al 2001).

Within the framework of the aforementioned national project, the German blackheaded Mutton Sheep $(\mathrm{GBH})$, Hampshire Down (HD) and Lincoln (L) were brought to the Konya Livestock Research Institute in 1989 and the Merino (CAM, Central Anatolian Merino) sheep and GBH and HD included in this enterprise were crossbreed with native Akkaraman (AK) and Awassi breeds which are also included in this enterprise (Tekin et al 2001). HD, CAM and GBH crossbreds and $\mathrm{HD}, \mathrm{AK}$ and $\mathrm{GBH}$ crossbreds have been raised indoors since 1997 and type fixation studies were inititaed through selection. As a result, the sheep named Hasmer $\quad(31.25 \% \mathrm{HD}, 37.5 \% \mathrm{CAM}$ and $31.25 \% \mathrm{GBH})$ and Hasak (31.25\% HD, 37.5\% AK and $31.25 \% \mathrm{GBH})$ were developed. When considering that the Central Anatolian Merino was obtained as a result of crossbreeding the German Mutton Merino (GMM) with Akkaraman in the previous years and that it has 20\% genotype of the Akkaraman (Düzgüneş et al., 1983), the approximate genotype ratios in the Hasmer

*Corresponding author email: ugurtrabzon60@hotmail.com 
should be evaluated as $31.25 \% \mathrm{HD}, 30.0 \% \mathrm{GMM}$, $7.5 \%$ AK and $31.25 \% \mathrm{GBH}$.

GBH and GMM originate in Germany and HD originates in UK. The common characteristics of these three breeds are to have meat type traits and to have high fleece yields (Özcan, 1990). The fertility rate in lamb meat production is also a very important factor. It is possible to breed more lambs in the sheep flock with high fertility rate and to produce more lambs in total. The fertility of these three breeds is satisfactory (the offspring can be obtained between 120 and 155 from hundred sheep) (Özcan 1990).

In the Official Gazette dated November 12, 2014 and numbered 29173, Hasak and Hasmer were registered as native breeds by the amendment made in the Communique (communique no: 2004/39)on the registration of domestic animal breeds and lines (Anonymous 2014).

Although there are some studies about yield traits related to Hasak and Hasmer breeds in literature, it is understood that studies on fertility have not been conducted sufficiently. The aim of this study was to determine the fertility traits of Hasak and Hasmer breed sheep raised in the Bahri Dağdaş International Agricultural Research Institute (BDIARI).

\section{Materials and Methods}

In this study, insemination, birth and records pertaining to lambs obtained in 2017-2018 years for 110 Hasmer and 170 Hasak sheep raised in the BDIARI Sheep Breeding Unit were used.

In the enterprise, sheep are fed based on the grazing during the day to the extent that the climate allows, and additional feed is given when they return to the sheep pen in the evening. However, it is paid special attention to the feeding of sheep at the end of the pregnancy when the energy and protein requirements are high and during the periods when the lactation milk yield is high.

The sheep are given the concentrated feed prepared in the institute and dry alfalfa grass of 400-500 g/per sheep in the last six weeks of the pregnancy and 800$1000 \mathrm{~g} /$ per sheep from lamb suckling period to the beginning of grazing.

Flushing is applied to the sheep during the mating season. The flushing application was started four weeks before the mating and continued for two weeks after the mating. For this purpose, four weeks before the insemination, the concentrated feed was started 100 g/per sheep in addition to roughage and this quantity was gradually increased to $500 \mathrm{~g}$ a week before the insemination. Additional feeding was also started in the rams about four weeks before the mating and continued for two to three weeks after the mating. Approximately $300-400 \mathrm{~g}$ of crushed grains per day was given to the rams when the mating was approached. At the time of insemination, $500 \mathrm{~g}$ of oatmeal and, apart from that,
$150 \mathrm{~g}$ of soybean meal were given as protein supplement.

The inseminations were made between August and October through hand mating. The teaser ram is included in herd in the oestrus cycle of the sheep and the ewes with oestrus activity were determined and inseminated the breeding rams. The insemination dates and the numbers of rams and ewes were recorded. Births usually correspond to the months of January to March. The birth dates of ewes giving birth and the birth weights of the lambs (within 24 hours and with a sensitivity of $100 \mathrm{~g}$ ), their sex and birth types were recorded. Lambs were weaned when they were three months old (in the 90th day).

In the study, the fertility parameters examined and the equations used in the calculation are as follows:

Conception rate, $\%=$ Number of pregnant sheep $/$ the number of ewes exposed to the ram $\mathrm{x} 100$

Prolificacy, $\%=$ the number of lamb born $/$ the number of ewes lambing x 100

Productivity of flock, $\%=$ the number of lambs weaned /Number of ewes exposed to the ram $\mathrm{x} 100$

Viability, $\%=$ Number of lambs living in the ninetieth day / the number of lamb born $\mathrm{x} 100$

The least squares method was used in the analysis of the factors for which the effects on fertility parameters were examined. The method was applied using Harvey's (1987) computer package program. Duncan test was used to determine the significance of the differences between the groups' averages. When applying the least squares method, the existence of the following models is accepted;

Yijl $=\mu+\mathrm{a} i+\mathrm{b} j+\mathrm{e} i j l$

The following equation is added to the model in order to analyse the effects of survival rate and sex and birth type

Yijkl $_{(m n)}=\mu+\mathrm{a}_{i}+\mathrm{b}_{j}+\mathrm{c}_{k}+\mathrm{d}_{l}+\mathrm{s}_{m}+e i j k l_{(m n)}$

Yijkl $l_{(m n)}$ : The fertility record of any ewe (lamb in survival rate) expressed by the measure examined; i.e. for Prolificacy, $i$ is the age, $j$ is the year in which she gave birth, $\mathrm{k}$ is the breed and 1 is number of lamb she gave birth

$\mu$ : overall mean

$\mathrm{a}_{i}:$ the effect of year $i=1,2(2017-2018)$

bj: age of ewe $j=2,3,4,5,6,7)$

$\mathrm{c}_{k}$ : Type of birth $k=1,2$ (single, twin)

$\mathrm{d}_{l}$ : the sex of lamb $l=1,2$ (Male, Female)

$\mathrm{Y}_{i j k l}: i$. year, $j$. age, $k$. type of birth, $l$. sex

$\mathrm{e}_{i j k l}:$ error 
$\mathrm{e}_{i j k l(m n)}=$ the effect of error (it is accepted that the zero

variance of the means of e's was $\sigma_{e}^{2}$ ).

Duncan's multiple range test using MSTAT-C Range Program (1989) was used to make comparisons among the subclass means.

Table 1

Least-squares means and standard errors for conception rate, prolificacy, productivity and viability of Hasmer and Hasak sheep

\begin{tabular}{|c|c|c|c|c|c|c|c|c|}
\hline \multirow{2}{*}{$\begin{array}{c}\text { Factors } \\
\text { Overall mean }\end{array}$} & \multicolumn{2}{|c|}{ Conception Rate, \% } & \multicolumn{2}{|c|}{ Prolificacy, \% } & \multicolumn{2}{|c|}{ Productivity, $\%$} & \multicolumn{2}{|c|}{ Viability, \% } \\
\hline & 642 & $87.27 \pm 0.01$ & 571 & $117.16 \pm 0.01$ & 645 & $103.34 \pm 0.02$ & 648 & $87.06 \pm 0.01$ \\
\hline Age of ewe's (bj) & & NS & & $* *$ & & $\mathrm{NS}$ & & NS \\
\hline 2 & 151 & $85.77 \pm 0.02$ & 132 & $107.59 \pm 0.03^{\mathrm{f}}$ & 152 & $101.18 \pm 0.04$ & 140 & $82.05 \pm 0.03$ \\
\hline 3 & 144 & $88.09 \pm 0.02$ & 133 & $110.65 \pm 0.03^{\mathrm{e}}$ & 149 & $100.89 \pm 0.04$ & 146 & $87.65 \pm 0.03$ \\
\hline 4 & 119 & $91.27 \pm 0.02$ & 106 & $121.69 \pm 0.03^{\mathrm{b}}$ & 115 & $109.94 \pm 0.05$ & 127 & $92.68 \pm 0.03$ \\
\hline 5 & 92 & $85.61 \pm 0.03$ & 81 & $118.49 \pm 0.04^{\mathrm{d}}$ & 92 & $102.96 \pm 0.05$ & 93 & $87.93 \pm 0.03$ \\
\hline 6 & 56 & $89.23 \pm 0.04$ & 50 & $125.26 \pm 0.05^{\mathrm{a}}$ & 56 & $106.42 \pm 0.07$ & 63 & $82.41 \pm 0.04$ \\
\hline 7 & 80 & $83.62 \pm 0.03$ & 69 & $119.27 \pm 0.04^{\mathrm{c}}$ & 81 & $98.66 \pm 0.05$ & 79 & $89.64 \pm 0.03$ \\
\hline Year $\left(a_{i}\right)$ & & NS & & $*$ & & NS & & NS \\
\hline 2017 & 310 & $88.71 \pm 0.02$ & 278 & $113.86 \pm 0.02$ & 311 & $101.84 \pm 0.03$ & 308 & $88.41 \pm 0.02$ \\
\hline 2018 & 332 & $85.81 \pm 0.02$ & 293 & $120.45 \pm 0.02$ & 334 & $104.84 \pm 0.03$ & 340 & $85.71 \pm 0.02$ \\
\hline Breed-Genotype $\left(c_{k}\right)$ & & $* *$ & & $*$ & & NS & & $\mathrm{NS}$ \\
\hline Hasmer & 250 & $83.26 \pm 0.02^{\mathrm{a}}$ & 211 & $120.90 \pm 0.02^{\mathrm{a}}$ & 251 & $102.06 \pm 0.03$ & 248 & $87.40 \pm 0.02$ \\
\hline Hasak & 392 & $91.27 \pm 0.01^{\mathrm{b}}$ & 360 & $113.41 \pm 0.02^{b}$ & 394 & $104.63 \pm 0.03$ & 400 & $86.72 \pm 0.02$ \\
\hline Type of birth $\left(\mathrm{d}_{\mathrm{l}}\right)$ & & & & & & & & $*$ \\
\hline Single & & & & & & & 488 & $90.88 \pm 0.01^{\mathrm{a}}$ \\
\hline Twin & & & & & & & 160 & $83.33 \pm 0.02^{\mathrm{b}}$ \\
\hline Sex of lamb $\left(\mathrm{s}_{\mathrm{m}}\right)$ & & & & & & & & NS \\
\hline Male & & & & & & & 337 & $85.57 \pm 0.02$ \\
\hline Female & & & & & & & 311 & $88.56 \pm 0.02$ \\
\hline
\end{tabular}

Means followed by different letters within clases differ: * $\mathrm{P}<0.05$; ** $\mathrm{P}<0.01$; NS, non-significant.

\subsection{The Measures of Reproductive Performance}

The least-squares mean for conception rate was $87.27 \pm 0.01 \%$. This rate was similar to $87.5 \%$ for Akkaraman reported by (Yalçın \& Aktaş 1976). However, this conception rate was higher than reported by (Yıldız \& Denk 2006) for Akkaraman (85.19\%), and was lower than that obtained by (Özbey \& Akcan 2000) for Akkaraman (93.0\%), by Mohammadi et al (2013) for Makooei (93.0\%), by (Öztürk \& Pembeci 2016) for Akkaraman (91.44\%) and Büyüktekin \& Öztürk (2018) for Akkaraman ( $91.27 \%$ ).

The average prolificacy for the flock of Akkaraman and Awassi was calculated as $117.16 \pm 0.01 \%$. This value was same to $117.00 \%$ for Karacabey merino reported by Sezenler et al (2013), and was similar to that for Karakaş sheep (118.00 \%) reported by Ülker et al (2004), but was lower than the prolificacy of Awassi (Öztürk \& Pembeci 2016) and Akkaraman ewes (Büyüktekin \& Öztürk, 2018), 129.27 and $135.0 \%$, respectively. Whereas, higher than $114.9 \%$ value reported by Köycü (2017) for Kivircik.

The productivity was found as $103.34 \pm 0.02 \%$ in the present study. This value is higher than the findings of Özcan et al (2002); (92.8\%) and (Büyüktekin \& Öztürk 2018); (86.38 \%) for the Akkaraman breed. In contrast, this value was lower than the productivity of Akkaraman (108.23\%) and Awassi (111.40\%) reported by (Öztürk \& Pembeci 2016).

\section{Results and Discussion}

The least-squares means with their standard errors and test of significance for conception rate, prolificacy, productivity and viability of Hasak and Hasmer sheep are shown in Table 1. 
(Thieme et al. 1999; Öztürk \& Pembeci 2016; Büyüktekin \& Öztürk 2018). According to (Öztürk \& Pembeci 2016; Büyüktekin \& Öztürk 2018) the effect of dam age on productivity was significant. These findings were not similar with the current study's result. But, (Vanlı \& Özsoy 1988) reported that no significant effect on productivity for Awassi sheep. The dam age's effect on viability was reported as significant (Thieme et al., 1999; Ünal et al 2003; Öztürk \& Pembeci 2016). (Ekiz \& Altınel 2006; Koç 2004 and Büyüktekin \& Öztürk 2018) have found the effect of main age to the living force to the lambs similar to the result of the Study.

\section{Year}

The factor "year" includes climatic, management, nutrition and husbandry elements, and it affect only prolificacy in the present study $(\mathrm{P}<0.05)$. Mohammadi et al (2013) in Makooei sheep, (Ozturk \& Pembeci 2016) Akkaraman and Awassi breeds, and Büyüktekin \& Öztürk (2018) in Akkaraman sheep have found that the effect of year factor on the prolificacy was important. There were no studies reporting the insignificant effect of the year factor.

\section{Breed}

As seen in the Table 1, it is concluded that Hasmer ewes were superior in terms of prolificacy than Hasak, in contrast Hasak ewes were superior in terms of conception rate than Hasmer, but there was no difference between the breeds with regard to the other criteria (productivity and viability). The same finding has been reported by Öztürk \& Pembeci (2016) for Akkaraman and Awassi sheep in Konya. Prolificacy has been reported as the most appropriate measure for the comparison of sheep breeds in terms of reproductive performance (Köprücü 1975). According to this result it can be said that Hasmer has a higher reproductive efficiency than Hasak in conditions of BDIARI. This confirms the findings of (Pekel \& Güney 1976). Because the differences among sheep breeds in respect of reproductive performance can be caused by the various environmental conditions, different selection purposes and also may be depended on changes of additive genes frequencies by chance and isolations.

\section{Sex of Lamb}

The viabilities of 337 male and 311 female lambs were $85.57 \pm 0.02 \%$ and $88.56 \pm 0.02 \%$, respectively. Sex effect on the viability was not significant,. Koncagül et al (2013) for zom sheep, Aktaş et al (2014) for Akkara-man sheep, Öztürk \& Pembeci (2016) for Akkaraman and Awassi sheep and Büyüktekin \& Öztürk (2018) for Akkaraman sheep found that the effect of lamb sex on viability was insignificant. However, Pekel (1973) reported that male lambs had higher viability than females for Akkaraman and Awassi sheep

\section{Type of Birth}

The average viability of 488 single and 160 twin lambs were $90.80 \pm 0.01 \%$ and $83.33 \pm 0.02 \%$, respectively. The difference between the averages is significant
$(\mathrm{P}<0.05)$. This result is consistent with the literature in general (Ünal et al 2003; Öztürk \& Pem-beci 2016). However, some researchers have reported the viability in favor of twin lambs (Özcan at al 2002; Ekiz \& Altınel 2006; Büyüktekin \& Öztürk 2018). The effect of lamb birth type on viability is related to ewe's pregnancy, the care of her young after birth, and her ability to produce enough milk. It is also related to the birth weight of the lamb.

\section{Conclusion}

For more meat production, high fertility is also required from the sheep. In this study, it is concluded that fertility of Hasak and Hasmer developed as meat-type (in the conditions in which care, management and feeding are considered to be relatively good) was not high. The new studies are needed in order to properly estimate the fertility of Hasak and Hasmer.

\section{References}

Aktaş AH, Çolak M, Tekin ME, Akay N, Yılmaz Canatan T \& Dursun S (2014). The Possibilities to Benefit From Hasmer and Hasak Sheep Types with Akkaraman Sheep in Breeders' Flocks for Slaughter Lamb Production. Eurasian Journal of Veterinary Sciences 30 (4):210-216.

Anonymous (2014). T.C. Cumhurbaşkanlığı Resmi Gazate, http://www.resmigazete.gov.tr/, Visit date: 15 April 2019.

Büyüktekin M, Öztürk A (2018). Effects of Some Factors on Reproduction Performance of Akkaraman Sheep in Breeder Flocks in Konya Province, Turkey, Selcuk Journal Agriculture and Food Sciences 32 (1), 87-90.

Düzgüneş O, Eliçin A, Sönmez R, Yalçın BC (1983). The Genetic Breeding of Sheep in Turkey. The Mediterranean International Symposium on Sheep and Goat Production, Ankara, 23-33.

Ekiz B, Altınel A (2006). The Growth and Survival Characteristics of Lambs Produced By Commercial Crossbreeding Kivircık Ewes with $\mathrm{F}_{2}$ Rams with The German Black-headed Mutton Genotype. Turk Journal of Veterinary and Animal Sciences, 30:507-512.

Harvey WR (1987). User's Guide for LSMLMW PC-1 Version Mixed Model Least-Squares and Maximum Likelihood Computer Program. Ohio State University, Columbus, Mimeo.

Koç RG (2004). The Survival Rate of Lambs and Some Effective Factors Under Breeder Conditions. Institute for Science, Adnan Menderes University Institute of Science and Technology, Aydın, 31-37.

Koncagül S, Vural E, Karataş A, Akça N, Bingöl M (2013). Reproductive Performance of Ewes and Growth Characteristics of Lambs in Zom Sheep 
Reared in Karacadağ District. Kafkas University Journal of Veterinary Faculty 19 (1): 63-68.

Koyuncu M, Akgün H (2018). Some Fertility Traits of Kivircik Sheep in Rural Farms). Journal of Animal Production 59 (1):33-40.

Köycü E (1975).Predictions of Factors Affecting Reproductive Fertility in Merino and Morkaraman Herds of Atatürk University. Atatürk university Publication. Nu:377, Erzurum.

Mohammadi H, Shahrebabak MM, Shahrebabak HM (2013). Analysis of Genetic Relationship be-tween Reproductive vs. Lamb Growth Traits in Makooei Ewes. J.Agr. Sci. Tech.2013 (15):45-53.

Özbey O, Akcan A (2000). The Yield Performance of Akkaraman, Morkaraman and Awassi sheep in Semi-intensive Conditions, I. Fertility and Milk Yield. Journal of Veterinary Sciences 16(1):109120.

Özcan L (1990). Sheep Breeding. Ministry of Agriculture, Forestry and Village Affairs Publication Department, Ankara, 25-26.

Özcan M, Yılmaz A, Akgündüz M (2002). Crossbreeding Between Turkish Merino, Sakiz and Kıvirc1k Sheep Breeds and Studies on increasing the Possibilities of Meat Yields of The Lambs to the Slaughter, 1. Fertility, Survival Rate in the Lambs and Growth. Turk Journal of Veterinary and Animal Sciences 26:517-523.

Öztürk A, Pembeci M (2016). Reproductive Performance of Akkaraman and Awassi Sheep Flocks in The State Farm of Tigem Gözlü. Selçuk Journal Agriculture and Food Sciences 30 (1):17-20.

Pekel E (1973). Utilization Possibilities From Awassi Sheep in İncreasing the Milk Yield of Ak-karaman Sheep. Ankara University publications of Faculty of Agriculture, No:43, Ankara.

Pekel E, Güney O (1976). The Milk Yield of Akkaraman Sheep in the Central Anatolian Region and Development Studies on Some of its Traits by Using Awassi Sheep. Turkish Sheep Breeding Seminar, 15-17 November 1976, Ankara.
Sezenler T, Soysal M, Yıldırır M, Yüksel MA, Ceyhan A, Yaman Y, Erdoğan İ, Karadağ O (2013). The Lamb Yield of Karacabey Merino Ewes and The Effect of Some Environmental factors on The Growth Performance of Lambs. Journal of Tekirdag Agricultural Faculty 10(1): 40-47.

Thieme O, Karazeybek M, Özbayat Hİ, Sözmen R (1998). Performance of Village Sheep Flocks in Central Anatolia II. Fertility and Productivity of Ewes. Turk Journal of Veterinary and Animal Science 23:175-181.

Tekin ME, Gürkan M, Karabulut O, Düzgün H (2001). Performance Test and Selection Studies in Some Meat-type Breeds of Merino, Akkaraman and Awassi and Their Crossbreeds, I. Fertility and Survival Rate, (Hasmer, Hasak, Hasiv and Limner), I. Fertility and Viability. Livestock Research Journal 11(2):1-8.

Ünal N, Atasoy F, Akçapınar H, Erdoğan M (2003). Fertility Traits, Survival Rate and Growth Characteristics of Karayaka and Bafra (Chios x Karayaka G1) Genotypes. Turk Journal of Veterinary and Animal Sciences 27(2003):265-272, (in Turkish).

Ülker H, Gökdal Ö, Aygün T, Karakuş F (2004). Comparison of Some Reproductive Traits of Karakaş and Norduz Sheep. Yüzüncü Yll University Agricultural Faculty Journal of Agricultural Sciences 14(1):59-63(in Turkish).

Vanlı Y, Özsoy MK, Dayığlu H, Doğrul F (1990). The Effects of Transferrin Polymorphism and Some Environmental Factors on Yield Traits of Merinos, Morkaraman, Awassi, Karagül ve Tuj Sheep. II. The Lamb Yield per Sheep mat-ed. Turk Journal of Veterinary and Animal Sciences (14):83-95.

Yalçın, BC, Aktaş G (1976). Comparative Studies on The Yield Traits of Ile de France and Akka-raman Sheep and Their Crossbreeds. Istanbul University, The Journal of Faculty of Veterinary 2(1):21-40.

Yildiz N, Denk H (2006). Various Yield Chararacteristics of Akkaraman Sheep Grown by the People in the Region of Van 1. Fertility and Milk Yield Char-acteristics. Firat University Journal of Health Sciences 20(1):21-27. 